\title{
PROSPECTIVE EVALUATION OF THE CLINICAL RISK FACTORS IN TERMS OF PROGNOSIS IN ACUTE DIFFUSE PERITONITIS IN TRIBAL INDIA
}

\author{
Lalit Vishvanath Tamgadge1, Rupesh Kawadu Sondawle², Ashok Gajbhiye ${ }^{3}$
}

${ }_{1}^{1}$ Assistant Professor, Department of General Surgery, GMC, Chandrapur, Maharashtra, India.

${ }^{2}$ Senior Resident, Department of General Surgery, GMC, Chandrapur, Maharashtra, India.

${ }_{3}^{3}$ Professor and HOD, Department of General Surgery, GMC, Chandrapur, Maharashtra, India.

\section{BACKGROUND}

ABSTRACT

Throughout the evolution of surgery, peritonitis has been a continuous diagnostic and therapeutic challenge. Even in some centers, due to lack of armamentarium in tribal India, surgeons have to depend more on clinical risk factors for diagnosis and early management.

The aim of this study was to evaluate clinical risk factors affecting mortality and morbidity in patients of acute diffuse peritonitis.

\section{MATERIALS AND METHODS}

This was a hospital based, longitudinal descriptive study of 120 high risk emergency patients of acute diffuse peritonitis who were analysed and treated with the best available measures in the center.

\section{RESULTS}

The overall mortality in the study group was $11 \%$. Significant risk factors in the analysis included age $>50$ years $(p=0.02)$, delay of more than 24 hours in presenting for evaluation ( $\mathrm{p}=0.002)$. The morbidity i.e. duration of hospital stay was observed in $73 \%$ who stayed for 7-14 days. It increased significantly with advanced age $>50$ years $(p=0.009)$ and in delayed duration of presenting symptoms of more than 24 hours $(\mathrm{p}=0.02)$.

\section{CONCLUSION}

Clinical risk factors as we studied in our present study found to govern the outcome of patients. All patients were high risk emergency patients and immediate intervention with proper evaluation was done change the out come in these patients.

\section{KEY WORDS}

Acute Diffuse Peritonitis, Mortality, Morbidity.

HOW TO CITE THIS ARTICLE: Tamgadge LV, Sondawle RK, Gajbhiye A. Prospective evaluation of the clinical risk factors in terms of prognosis in acute diffuse peritonitis in tribal India. J. Evolution Med. Dent. Sci. 2019;8(01):10-13, D0I: 10.14260/jemds/2019/3

\section{BACKGROUND}

Throughout the evolution of surgery, peritonitis has been a continuous diagnostic and therapeutic challenge. Even today, with the availability of advanced and sophisticated medical technology, this remains true.

After the discovery of penicillin by Fleming, there was no great improvement in treatment results. Only since the mid 1970 s, we have been able to register further improvement down to about $30 \%$ mortality, due to broad spectrum antibiotics, improvement of ICU monitoring and a more aggressive and optimized surgical approach. Still no definitive therapy exists that can successfully treat sepsis and its complications. The diagnosis is supported by clinical signs, e.g. abdominal pain or tenderness, distension, nausea, diminished intestine sounds, fever, shock abdominal, radiographic and microbiologic evidence. Presently, APACHE II Score (Acute Physiological And Chronic Health Evaluation Peritonitis Index (MPI) based on analysis of possible risk

'Financial or Other Competing Interest': None.

Submission 14-12-2018, Peer Review 27-12-2018,

Acceptance 29-12-2018, Published 07-01-2019.

Corresponding Author:

Lalit Vishvanath Tamgadge,

Mahesh Nagar,

Near Home Guard Office,

Tukum, Chandrapur, Maharashtra, India

E-mail: drlalit.t@gmail.com

DOI: $10.14260 /$ jemds $/ 2019 / 3$ factors in patients of peritonitis. The score considers clinical risk factors routinely found in pre-operative and transoperative registers. ${ }^{[4]}$ Various authors have reported APACHE to be better system for prognostication of the outcome of patients with peritonitis, ${ }^{[5-6]}$ while others concluded that MPI provides a more reliable means of risk evaluation.[7] The prognosis and outcome of peritonitis depends upon interactions of many factors including; patient related factors, disease specific factors, and diagnostic and therapeutic interventions. Categorizing patients into different risk group would help prognosticate the outcome, select patients for intensive care and determine operative risk, thereby helping to choose the nature of the operative procedures.

Still any of the scoring systems are not yet proven confirmatory to prognosticate the case of acute diffuse peritonitis with limited resources. So, it prompted us to undertake this hospital based, longitudinal descriptive study, unicentric study to assess severity, need for early surgical intervention, morbidity and mortality in patient with peritonitis.

\section{MATERIALS AND METHODS}

It was a hospital based, longitudinal descriptive study and was conducted in the Department of Surgery, from October 2016 to August 2018. A total of 120 cases selected in the study who had attended Surgery OPD and admitted to Department of Surgery, as well as include those patients presenting to the Emergency Department with features of Acute Diffuse Peritonitis. These admitted patients were 
resuscitated immediately and meanwhile, they were evaluated carefully for the presence of co-morbid conditions and surgical fitness. A team of surgeons, anaesthesiologist and physician evaluated each of high-risk surgical patients for suitability for surgery under general anaesthesia.

\section{Inclusion Criteria}

- Patient diagnosed of having secondary peritonitis irrespective of age and sex.

- Patient diagnosed of having secondary peritonitis requiring emergency surgery.

- Patient diagnosed of having secondary peritonitis intraoperatively.

\section{Exclusion Criteria}

- Patient with doubtful diagnosis.

- Patient diagnosed with peritonitis due to chronic diseases like TB, HIV, Hepatitis, Malignancy.

- Patient who refused to co-operate.

- Pregnant patient.

After resuscitation, those who were fit for operation by team of anaesthesiologist and physician were operated. Postoperative evaluation for the recovery of these patients in terms of morbidity and mortality was done.

\section{Statistical Analysis}

Statistical analysis was performed using Statistical software for social science Version 16 (SPSS 16). Descriptive statistics (mean, \%) were used to summarize baseline characteristics. Association between two categorised variables was analysed by chi square test. The $p$ value $<0.05$ was considered to be statistically significant.

\section{RESULTS}

The age of the patients in this study ranged between 12-78 years with median age of 41.5 years. The mean age of these patients was 41.70. Maximum number of patients was in the age group $30-39$ years $(22.0 \%)$ and $40-49$ years (19.0\%). Out of 120 patients included in the study $85(71 \%)$ were male and $35(29 \%)$ were female. Abdominal pain was the presenting complaint in most of the patients $(120 ; 100 \%)$ as a diffuse pain all over the abdomen from the time of onset (99/120; 83\%). A few patients with appendicular perforation experienced pain in the right iliac fossa which subsequently spread all over the abdomen (12/120; 10\%). Patients who were eventually diagnosed with necrotising pancreatitis had epigastric pain radiating to back at time of onset $(10 / 120$; $8.33 \%$ ). Nausea, vomiting and anorexia are very nonspecific findings. These were present in 71 (59\%) patients of peritonitis. Thirty-three (28\%) patients complained of absolute constipation since the time they experienced pain in abdomen. Seventy-five out of 120 patients (62\%) complained of distension. Fifty-two out of 120 (44\%) had dyspnoea and 47 (39\%) had fever and most of these patients had enteric perforation $(14 / 120 ; 12 \%)$, appendicular perforation $(12 / 120 ; 10 \%)$ and necrotising pancreatitis $(10 / 120 ; 8 \%)$.

The mean duration of symptoms which the patients have suffered was 2.50 days. Most of the patients presented to the hospital 2 days after onset of symptoms (58/120; 48\%). Fifty-four patients had tachycardia (i.e. pulse rate $>100 \mathrm{bpm}$ ) and 4 patients had irregular pulse due to their underlying cardiac disease. Rigidity was found to be present in 89 (74\%) cases.

In our study liver dullness was obliterated in 95 cases (79\%). Bowel sound was absent in 89 cases (74\%), sluggish in 31 of cases (25\%).) Anaemia was observed in $86 \%$ $(103 / 120)$. Severe anaemia (i.e. $\mathrm{Hb}<7 \mathrm{~g} / \mathrm{dL}$ ) was observed in 12 patients at the time of admission. Forty-six (38\%) had hyponatremia (i.e. Serum $\mathrm{Na}^{+}<135$ meq/L) and 5 patients had hypernatremia (i.e. Serum $\mathrm{Na}^{+}>145 \mathrm{meq} / \mathrm{L}$ ) at the time of admission. Serum potassium level was below normal range (i.e. Serum $\mathrm{k}^{+}<3.5 \mathrm{meq} / \mathrm{L}$ ) in 28 (23\%) patients. An electrocardiographic change of hypokalaemia was present in 17 out of these 28 patients. Hyperkalaemia (i.e. Serum $\mathrm{K}^{+}>$ $5.5 \mathrm{meq} / \mathrm{L})$ was present in 6 patients (5\%). These six patients had severe renal failure. The baseline creatinine value of most of the patients was unknown. Therefore, the standard criteria for diagnosis of acute renal failure was taken to be serum creatinine $>2 \mathrm{mg} / \mathrm{dL}$. Forty-five out of 120 patients (38\%) met the criteria of acute renal failure.

Free gas under diaphragm was present in $80(67 \%)$ cases. Multiple fluid levels in erect posture X-ray view was found in $10(8 \%)$ cases due to paralytic ileus. Large amount fluid collection in the peritoneum gave a picture of haziness in the X-ray of $7(6 \%)$ cases. An electrocardiograph of all the patients showed abnormality in 19 patients. Four patients had underlying cardiac disease. Rest 15 patients had abnormal ECG due to electrolyte imbalance and recent onset rhythm abnormality.

Forty-Three patients had pre-existing medical illness. Type 2 diabetes mellitus and hypertension was present in 20 (8\%) and 11 (9\%) cases respectively. Four patients had previous coronary events. Chronic kidney disease and chronic liver disease was present in 2 and 4 patients respectively. Two patients had chronic respiratory illness. Among co-morbid conditions, Type 2 DM (20/43; 46.5\%) and Hypertension $(11 / 43 ; 25.5 \%)$ affects the disease progression to great extent.

Active search for aetiology of peritonitis could establish diagnosis in all patients. Most common aetiology of peritonitis was peptic perforation which accounted for $57 \%$ of total cases. Among mild severity cause of peritonitis was sealed perforation seen in $7 \%$ of cases. Enteric perforation as a cause of peritonitis was present in $12 \%$ of cases, whereas appendicular perforation was present in $10 \%$ of cases. Blunt trauma abdomen with biliary peritonitis or leading to perforation was found in 6 patients. Ten patients of necrotizing pancreatitis causing diffuse peritonitis were present. We encountered 1 case of gall bladder perforation due to calculus. Other rare causes were Gastric perforation in 2 patients, Post-op intestinal leak in 5 patients, Ruptured abscess liver in 3 patients, Subphrenic abscess in 1 patient, perforated cecal diverticulosis in 1 patient. Thirteen patients died and all these patients were critically ill and belong to the ASA score $\mathrm{V}$ as decided by the group of surgeons, anaesthesiologist and physician.

Overall, mortality in the study population was $11 \%$ $(13 / 120)$. Most of the patients died pre-operatively $(9 / 13$; $69.23 \%)$, followed by post-operative $(3 / 13 ; 23.07 \%)$ and intra-operative $(1 / 13 ; 7.69 \%)$. Of the patients who died preoperatively, most of them did not survive beyond $1^{\text {st }}$ day $(6 / 13 ; 46.15 \%)$.

Majority of patient died due to enteric perforation (7/14; $50 \%$ ). Peptic perforation was most common cause of peritonitis in age group of 30 to 50 years and accounted $7.01 \%$ (4/57) mortality. Other cause of mortality in our study 
group was post-op intestinal leak and accounted 40\% (2/5) mortality.

\section{Factors Affecting Mortality}

Sub-group analyses of mortality showed a significant increase in mortality in patients with age $\geq 50$ years than those $<50$ years $(19.51 \%$ vs. $6.32 \%$; $\mathrm{p}=0.02)$. Patients presenting more or less than 24 hours after onset of symptoms showed significant increase in mortality in patients presenting more than 24 hours $(30.0 \%$ vs. $7.0 \%$; $\mathrm{p}=0.002$ ). But there had been no significant difference in mortality between patients with or without co-morbid disease $(38.46 \%$ vs. $61.53 \%$; $p=0.83)$.

\section{Duration of Hospital Stay (Days)}

Out of 107 patients, $5(4.67 \%)$ patient were cured and discharged in less than 7 days. These patients had sealed perforation in majority. Other 78 (72.89\%) patients took 7-14 days to recover; these patients had Peptic perforation (39/57; 68.42\%), appendicular perforation $(9 / 12 ; 75 \%)$, Blunt trauma abdomen with peritonitis (5/6; 83.33\%), Necrotising pancreatitis (7/10; 70\%). Remaining 24(22.42\%) patients took more than 2 weeks to recover.

\section{Factors Affecting Morbidity}

Sub-group analyses of morbidity showed a significant increase in duration of hospital stay (days) in patient with age $>50$ years than those $<50$ years $(54.54 \%$ vs. $28.37 \%$; $\mathrm{p}=0.009$ ). Patients presenting more than 24 hours after onset of symptoms had a significant increase in duration of hospital stay than those presenting less than 24 hours $(38.70 \%$ vs. $7.14 \% ; \mathrm{p}=0.02$ ). But there had been no significant difference in morbidity between patients with or without co-morbid disease $(26.08 \%$ vs $36.84 \%$; $p=0.24)$. Total number of survived cases in our study was 107 , these patients were diagnosed and treated as per their cause and discharged after a hospital stay of less than or more than two weeks. Since Peptic perforation was most common cause of peritonitis in our study group, it accounted 73\% (39) cases stayed less than 2 weeks and $27 \%$ (14) stayed more than 2 weeks. Likewise, Sealed perforation (62\% \& 38\%), Enteric perforation (25\% \& $75 \%)$, Appendicular perforation (75\% \& 25\%), BTA with peritonitis/perforation $\quad(83 \% \quad \& \quad 17 \%)$, Necrotising Pancreatitis (70\% \& 30\%), Post-op intestinal leak (33\% \& $67 \%$ ), others (37\% \& 63\%) which include Gall bladder perforation, Gastric perforation, Ruptured abscess liver, Subphrenic abscess and perforated cecal diverticulosis.

\begin{tabular}{|c|c|c|c|c|c|}
\hline \multicolumn{3}{|c|}{ Mortality } & $\begin{array}{c}\text { No. of } \\
\text { Patients } \\
\end{array}$ & $\begin{array}{l}\text { Per } \\
\text { Dist }\end{array}$ & $\begin{array}{l}\text { rcentage } \\
\text { tribution }\end{array}$ \\
\hline \multicolumn{3}{|c|}{ No. Mortality } & 107 & & 89.00 \\
\hline \multirow{3}{*}{ Mortality } & \multicolumn{2}{|c|}{ Pre-operative } & 10 & & 8.00 \\
\hline & \multicolumn{2}{|c|}{ Intra-operative } & 1 & & 1.00 \\
\hline & \multicolumn{2}{|c|}{ Post-operative } & 2 & & 2.00 \\
\hline \multicolumn{6}{|c|}{ Table 1} \\
\hline \multicolumn{2}{|c|}{ Factors } & Mortality & \multicolumn{2}{|c|}{ No. Mortality } & p-Value \\
\hline \multirow{2}{*}{ Age } & $<50$ Yrs. & 5 & 74 & & \multirow{2}{*}{0.02} \\
\hline & $\geq 50$ Yrs. & 8 & 33 & & \\
\hline \multirow{2}{*}{$\begin{array}{l}\text { Duration of } \\
\text { Symptoms }\end{array}$} & $<24$ & 6 & 14 & & \multirow{2}{*}{0.002} \\
\hline & $>24$ & 7 & 93 & & \\
\hline \multirow{2}{*}{$\begin{array}{l}\text { Co-morbid } \\
\text { condition }\end{array}$} & Present & 5 & 38 & & \multirow{2}{*}{0.83} \\
\hline & Absent & 8 & 69 & & \\
\hline \multicolumn{6}{|c|}{ Table 2. Factors Affecting Mortality } \\
\hline
\end{tabular}

\begin{tabular}{|c|c|c|c|}
\hline Factors & \begin{tabular}{|c|} 
No. of \\
Patient Died \\
\end{tabular} & \begin{tabular}{|l|} 
Total No. \\
of Patient \\
\end{tabular} & Percentage \\
\hline Peptic perforation & 4 & 57 & 7.01 \\
\hline Sealed perforation & 0 & 8 & 0 \\
\hline Enteric perforation & 7 & 14 & 50.0 \\
\hline $\begin{array}{l}\text { Appendicular } \\
\text { perforation }\end{array}$ & 0 & 12 & 0 \\
\hline BTA with perforation & 0 & 6 & 0 \\
\hline $\begin{array}{l}\text { Necrotising } \\
\text { pancreatitis }\end{array}$ & 0 & 10 & 0 \\
\hline $\begin{array}{l}\text { Post-Op. Intestinal } \\
\text { Leak }\end{array}$ & 2 & 5 & 40.0 \\
\hline Others & 0 & 8 & 0 \\
\hline
\end{tabular}

\begin{tabular}{|l|l|l|}
\hline Duration (Days) & No. of Patients & Percentage Distribution \\
\hline
\end{tabular}

\begin{tabular}{|c|c|c|}
\hline < 7 Days & 5 & 4.67 \\
\hline 7 - 14 Days & 78 & 72.89 \\
\hline 14 Days & 24 & 22.42 \\
\hline \multicolumn{2}{|c|}{ Table 4. Duration of Hospital Stay } \\
\hline
\end{tabular}

\begin{tabular}{|c|c|c|c|c|}
\hline \multicolumn{2}{|c|}{ Factors (n) } & $<2$ Wks. & $\geq 2 \mathrm{Wks}$. & p value \\
\hline \multirow{2}{*}{ Age } & $<50$ Yrs. & 53 & 21 & \multirow{2}{*}{0.009} \\
\hline & $\geq 50$ Yrs. & 15 & 18 & \\
\hline \multirow{2}{*}{$\begin{array}{l}\text { Duration of } \\
\text { Symptoms }\end{array}$} & $<24$ & 13 & 1 & \multirow{2}{*}{0.02} \\
\hline & $>24$ & 57 & 36 & \\
\hline \multirow{2}{*}{$\begin{array}{c}\text { Co-morbid } \\
\text { Condition }\end{array}$} & Present & 24 & 14 & \multirow{2}{*}{0.24} \\
\hline & Absent & 51 & 18 & \\
\hline \multicolumn{5}{|c|}{$\begin{array}{l}\text { Table 5. Factors Affecting Morbidity } \\
\text { (Duration of Hospital Stay) }\end{array}$} \\
\hline
\end{tabular}

\begin{tabular}{|c|c|c|c|c|}
\hline Factors (n) & $\begin{array}{c}\text { < 2 Wks. } \\
\text { n (\%) }\end{array}$ & $\begin{array}{c}\geq 2 \text { Wks. } \\
\text { n (\%) }\end{array}$ & p Value & \\
\hline $\begin{array}{c}\text { Peptic } \\
\text { Perforation (53) }\end{array}$ & $39(73)$ & $14(27)$ & 0.09 & \\
\hline $\begin{array}{c}\text { Sealed } \\
\text { Perforation (8) }\end{array}$ & $5(62)$ & $3(38)$ & 0.84 & \\
\hline $\begin{array}{c}\text { Enteric } \\
\text { Perforation (8) }\end{array}$ & $2(25)$ & $6(75)$ & 0.011 & Significant \\
\hline $\begin{array}{c}\text { Appendicular } \\
\text { perforation (12) }\end{array}$ & $9(75)$ & $3(25)$ & 0.47 & \\
\hline $\begin{array}{c}\text { BTA with } \\
\text { peritonitis/ } \\
\text { perforation (6) }\end{array}$ & $5(83)$ & $1(17)$ & 0.35 & \\
\hline $\begin{array}{c}\text { Necrotising } \\
\text { pancreatitis (10) }\end{array}$ & $7(70)$ & $3(30)$ & 0.76 & \\
\hline $\begin{array}{l}\text { Post-Op. Intestinal } \\
\text { Leak (3) }\end{array}$ & $1(33)$ & $2(67)$ & 0.23 & \\
\hline Others (8) & $3(37)$ & $5(63)$ & 0.08 & \\
\hline
\end{tabular}
$(\mathrm{n}=71)$

\section{DISCUSSION}

The mean age of the patients in our study group was 41.70 years, which was high from the previous study done by Jhobta et al (36.8 years).[8] Yet a substantial number of patients $(n=41,34 \%)$ were above 50 years of age. This was in contrast to study done by Jhobta et al, where only $16 \%$ patients belong to $>50$ years of age. This disparity was probably explainable by the fact that the aforesaid study had considered all patients with peritonitis, while the present work included high risked emergency patients only.

Most of the patients (48\%) had presented to the hospital after 48 hours of onset of symptoms, this was because these 
patients were mostly referred from other health centres and due to lack of transport facility; they had delayed presentation. Previous authors have implicated the increase in criticality of patients with peritonitis to the delay in treatment initiation (Udwadia et al, 1963; Bhansali, 1976; Wittman, 1991).[8-11] Pre-existing co-morbid conditions were present in 43 patients (42\%). Jhobta et al (2006) observed that only $24 \%$ in his study group had underlying medical illness. ${ }^{[8]}$ The incongruency can be explained by the nature of this study in which we have selected only high risked emergency patients. The clinical presentation of the patients varied according to the aetiology of peritonitis.

This higher prevalence of tachycardia is probably due toxaemia and shock. Hypotension was present in 10 patients (8\%). Most of them were on inotrope support. Udwadia et al (1963) and Johbta et al (2006) reported hypotension in 9\% of their study population. ${ }^{[8-9]}$ Patients who did not have rigidity were mostly elderly or were suffering from severe concurrent medical illness. Leucopenia was present in $7 \%$ cases. Leucopenia was found in $57.12 \%$ of patients diagnosed as having enteric perforation. In rest of the patients, leucopenia was a sign of severe sepsis.

Elevated serum urea and/or creatinine were high in comparison to the findings of Jhobta et al (2006). Electrolyte imbalance was a major factor in the delay of surgery. The ratio of upper to lower gastrointestinal tract perforation was $4: 1$. Similar observation were made in studies on patients with peritonitis by Sharma et al (1991), Jhobta et al (2006) and Dorairajan et al (1995).[8,12-13] Overall mortality in our study population was $11 \%$. Wolter et al (1996) recorded mortality rate of $93.3 \%$ for patients with ASA score V while Crook et al (1997) observed a mortality of $100 \%$ in patients with ASA score V undergoing emergency surgery.[14] Mortality in patients with age above 50 years showed a significant increase in mortality in the elderly group. But there had been no significant difference in mortality between patients with or without co-morbid diseases. Patients presenting more than 24 hours after onset of symptoms had significant increase in mortality. This was probably due to the fact that all the patients who died were critically ill and the seriousness of the disease had more impact on the outcome than the presence or absence of co-morbid conditions. Morbidity showed a significant increase in duration of hospital stay (days) in patient with age $>50$ years. Patients presenting more than 24 hours after onset of symptoms had a significant increase in morbidity. But there had been no significant difference in morbidity between patients with or without co-morbid disease. This is due to the fact that majority of the patients with co-morbid conditions had not present in the age group of perforative peritonitis which is the main cause of Acute diffuse peritonitis in our study.

\section{CONCLUSION}

Clinical risk factors as we studied in our present study, found to govern the outcome of patients. Various factors like age of the patient, duration of symptoms, presence or absence of comorbid conditions influenced the mortality and morbidity rate of these patients. All the patients in study group were high risk emergency patients and immediate intervention with proper evaluation could be done to change the outcome in these patients. Our study could not explain the significant relationship of presence or absence of co-morbid conditions in these patients in terms of prognosis. Apart from these, unavailability of ICU care makes the management of severely ill patients even more difficult. Most of the patients are thus left to their fate except for the available supportive measures. Increased mortality poses a difficult challenge to the treating surgeons and health administrators. Despite the lack of wellmatched controls and multi-centricity, the intervention in the present study made it possible to prognosticate the patients with acute diffuse peritonitis up to optimum level.

\section{REFERENCES}

[1] Knaus WA, Wagner DP, Draper EA, et al. The APACHE III Prognostic system. Risk prediction of hospital mortality for critically ill hospitalized adults. Chest 1991;100(6):1619-36.

[2] Sawyer RG, Rosenlof LK, Adams RB, et al. Peritonitis into the 1990s: changing the pathogenesis and changing strategies in the critically ill. Am Surg 1992;58(2):82-7.

[3] Lemeshow S, Teres D, Avrunin SJ, et al. A comparison of methods to predict mortality of intensive care unit patients. Crit Care Med 1987;15(8):715-22.

[4] Linder MM, Wacha H, Feldmann $U$, et al. The Mannheimer peritonitis index. An instrument for the intraoperative prognosis of peritonitis. Chirug 1987;58(2):84-92.

[5] Meakins JL, Solomkin JS, Allo MD, et al. A proposed classification of intra-abdominal infections. Stratification of etiology and risk for future therapeutic trials. Arch Surg 1984;119(12):1372-8.

[6] Knaus WA, Draper EA, Wagner DP, et al. APACHE II: a severity of disease classification system. Crit Care Med 1985;13(10):818-29.

[7] Billing A, Frohlich D, Schildberg FW. Prediction of outcome using the Mannheim peritonitis index in 2003 patients. Peritonitis Study Group. Br J Surg 1994;81(2):209-13.

[8] Jhobta RS, Attri AK, Kaushik R, et al. Spectrum of perforation peritonitis in India - review of 504 consecutive cases. World Journal of Emergency Surgery 2006;1:26.

[9] Udwadia TE, Sen PK, Mody AE, et al. Acute duodenal perforation. An analysis of clinical findings and an evaluation of treatment in 317 cases. Ind J Med Sci 1963;17:321-8.

[10] Bhansali SK. Gastrointestinal perforations - a clinical study of 96 cases. J Postgard Med 1967;13(1):1-12.

[11] Whittman DH, Walker AP, Condon RE. Peritonitis and intra-abdominal infection. In: Schwartz S, Shires G, Spancer F, eds. Principles of surgery. $6^{\text {th }}$ edn. New York: McGraw-Hill 1991: p. 1499-83.

[12] Sharma L, Gupta S, Soin AS, et al. Generalised peritonitis in India - the tropical spectrum. Jap J Surg 1991;21(3):272-7.

[13] Dorairajan LN, Gupta S, Deo SV, et al. Peritonitis in India - a decade's experience. Tropical Gastroenterology 1995;16(1):33-8.

[14] Wolters U, Wolf T, Stutzer H, et al. ASA classification and perioperative variables as predictor of postoperative outcome. Brit J Anaesth 1996;77(2):217-22. 